\title{
POTENSI PEMANFAATAN LIMBAH CAIR TAHU MENJADI BIOGAS UNTUK SKALA INDUSTRI RUMAH TANGGA DI PROVINSI BANTEN
}

\author{
Sally, Yessica Putri Budianto, Meutia Wafa' K. Hakim, Warsono El Kiyat* \\ Departemen, Teknologi Pangan dan Gizi, Fakultas Ilmu Hayati, Universitas Surya \\ Email : warsono.el.kiyat@gmail.com
}

\begin{abstract}
Tofu is one of the most produced and consumed foods in Indonesia as a source of protein. Currently, most of the tofu producers in Indonesia are home industries with simple production equipment, especially in Banten. Tofu production mostly produces solid and liquid wastes. However, liquid waste contains high protein and amino acids that can pollute the environment if it is not treated properly. It is due to this waste has a high BOD, COD and TSS value. Therefore, the right method is needed in utilizing tofu liquid waste by tofu producers in Indonesia by biogas production. Biogas from liquid waste can be produced as methane or hydrogen. Tofu waste based biogas provided benefits from various aspects, such as environmental, economic, social and health aspects. On the other hand, tofu waste production can be one of the efforts to achieve the Sustainable Development Goals (SDGs) in Banten. It can be implemented to achieve clean water and sanitation points, as well as affordable and clean energy sources.
\end{abstract}

Keywords: biogas, hydrogen, methane, sustainable development goals, tofu liquid waste

\section{PENDAHULUAN}

Tahu adalah salah satu produk pangan yang merupakan produk olahan dari kacang kedelai yang dibuat dengan cara pemekatan protein kedelai. Tahu banyak dikonsumsi di Indonesia sebagai lauk yang mengandung protein tinggi. Selain itu, tahu juga merupakan sumber protein subtitusi bagi orang yang tidak mengonsumsi produk hewani (vegetarian/vegan). Konsumsi tahu di Indonesia pada tahun 2015 yaitu 7,49 kg/kapita, yang menunjukkan adanya kenaikan dari tahun 2012 (Wahyuningsih, 2016). Hal ini menyebabkan industri tahu berskala kecil sekitar 1,47\% (Kemenperin, 2016). Kenaikan jumlah industri tahu ini menyebabkan akumulasi limbah mengalami peningkatan.

Sementara itu, produsen tahu di Indonesia kebanyakan merupakan pabrik kecil dan sedang serta belum memenuhi persyaratan dan ketentuan pabrik pada umumnya, sesuai dengan regulasi yang berlaku di Indonesia. Hal ini sangat berpengaruh terhadap pelaksanaan produksi di pabrik tersebut, baik dari segi higiene, sanitasi, maupun penanganan limbah pabrik. Beberapa produsen limbah tahu yang kurang bertanggung jawab terhadap limbah ini sering membuang limbahnya dengan tidak benar, sehingga menimbulkan kerugian bagi masyarakat yang tinggal di sekitar pabrik. Limbah pabrik tahu ini dapat berbentuk padat seperti ampas kedelai, sementara limbah cair dari pabrik tahu biasanya merupakan air bekas mencuci, merendam, dan merebus kacang kedelai. Limbah cair dari pabrik tahu ini mengandung senyawa organik seperti protein, karbohidrat, dan lemak, sehingga apabila dibuang ke dalam sungai atau danau, maka airnya menjadi tercemar (Said et al., 2015). Pencemaran ini akan berdampak buruk bagi kesehatan masyarakat yang menggunakan air dari sumber tersebut. 
Jumlah pabrik tahu di Indonesia cukup banyak, yaitu sekitar 84.000 pabrik tahu berskala kecil dan menengah, serta biasanya pabrik-pabrik tahu ini merupakan usaha milik keluarga (Sadzali, 2010). Di Kota Tangerang sendiri, limbah pabrik tahu belum dapat ditangani dengan baik, sehingga menimbulkan pencemaran lingkungan. Pada Maret 2017, terdapat kasus limbah pabrik tahu yang mencemari Sungai Cisadane, yang terjadi akibat tidak adanya penanganan limbah yang layak dan sesuai dengan standar pabrik di Indonesia. Banyaknya pabrik tahu yang bertempat di tepi sungai, ditambah dengan tidak adanya penanganan limbah di sekitarnya dapat mengotori Sungai Cisadane. Air sungai ini menjadi sangat pekat, berwarna putih, dan di seluruh badan sungai meghasilkan bau yang tidak sedap. Tentunya hal ini sangat merugikan masyarakat serta menurunkan kelestarian lingkungan (Tangerang Pos, 2017).

Permasalahan limbah ini membuat banyak pihak memanfaatkan limbah cair pabrik tahu untuk diolah menjadi berbagai produk yang berguna, sehingga dapat mengurangi risiko pencemaran. Limbah tahu juga dapat dimanfaatkan menjadi beberapa jenis produk, salah satunya yaitu bahan bakar biogas. Biogas ini tentunya akan berguna bagi masyarakat, terutama di daerah pedesaan, yaitu sebagai sumber bahan bakar yang lebih ramah lingkungan. Dengan begitu, limbah air dari pabrik tahu dapat dibuang dengan aman dan secara bersamaan menghasilkan produk yang bermanfaat bagi masyarakat setempat.

\section{METODE}

Metode yang digunakan dalam kajian ini yaitu studi literatur. Metode ini dilakukan dengan cara mengkaji pemanfaatan limbah cair tahu dan potensinya untuk diolah menjadi biogas, yang dapat diaplikasikan pada skala industri rumah tangga di Provinsi Banten.
Sumber data yang digunakan pada kajian ini merupakan data sekunder yang didapatkan dari publikasi ilmiah seperti jurnal, buku maupun media internet. Hasil dari studi literatur diperoleh sebanyak 32 judul literatur yang digunakan untuk pelaksanaan kajian. Data yang diperoleh, kemudian dianalisis secara deskriptif (Rianti et al., 2018), dengan cara memaparkan dan membandingkan hasilhasil penelitian eksternal terkait potensi pemanfaatan limbah cair tahu. Adapun alur studi literatur yang digunakan, disajikan pada Gambar 1.

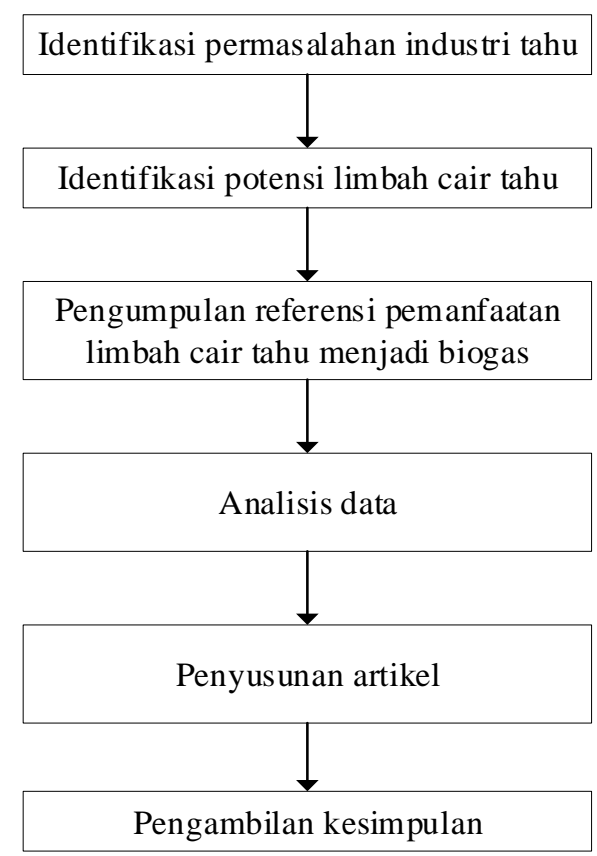

Gambar 1. Alur Studi Literatur

\section{HASIL DAN PEMBAHASAN}

\section{Limbah Cair Tahu}

Limbah cair tahu merupakan sisa air pembuatan tahu yang tidak menggumpal, sehingga menghasilkan air yang kental dan keruh, berwarna kekuningan, dan menghasilkan bau tidak sedap (Nohong, 2010). Limbah cair dapat berasal dari perendaman dan pencucian kedelai, pencucian alat produksi, penyaringan, dan pengepresan atau pencetakkan tahu (Arifin, 2012). Walaupun limbah cair tahu 
dianggap sebagai by product pembuatan tahu yang tidak lagi berguna, namun limbah cair tahu sebenarnya kaya akan kandungan bahan organik seperti protein dan asam amino. Di sisi lain, bahan organik ini dapat mencemari lingkungan, karena mengandung biochemical oxygen demand (BOD), chemical oxygen demand (COD), dan total suspended solid (TTS) yang tinggi (Husin, 2003). Selain mengandung bahan organik, limbah cair tahu juga mengandung beberapa jenis gas, seperti: oksigen $\left(\mathrm{O}_{2}\right)$, hidrogen sulfida $\left(\mathrm{H}_{2} \mathrm{~S}\right)$, amonia $\left(\mathrm{NH}_{3}\right)$, karbondioksida $\left(\mathrm{CO}_{2}\right)$, dan metana $\left(\mathrm{CH}_{4}\right)$. Gas metana, hidrogen sulfida, dan karbon dioksida dari limbah tahu ini berpotensi untuk dimanfaatkan kembali menjadi biogas (Ridhuan, 2012).

Kandungan lain yang cukup tinggi dalam limbah cair tahu yaitu nitrogen $(\mathrm{N})$, fosfor $(\mathrm{P})$, dan kalium $(\mathrm{K})$ yang berturutturut mencapai 43,37 mg/L, 114,36 mg/L dan 223 mg/L (Kusumawati et al., 2015). Kandungan N, P, dan $\mathrm{K}$ yang tinggi ini merupakan ancaman bagi lingkungan sekitar, karena dapat menyebabkan eutrofikasi yang berujung pada algae blooming (Widyastuti et al., 2015). Adapun solusi pemanfaatan yang dapat digunakan dengan adanya kandungan $\mathrm{N}, \mathrm{P}$, dan $\mathrm{K}$ yaitu dengan diolah menjadi pupuk organik (Siswoyo dan Hermana, 2017).

\section{Industri Rumah Tangga Pangan}

Industri rumah tangga pangan adalah unit usaha dengan pekerja 1-4 orang yang pelaksanaannya berlangsung di rumah, dengan peralatan produksi pangan yang masih bersifat manual atau semi otomatis (BPS, 2014). Pada umumnya, proses produksi dan manajemen dalam industri rumah tangga masih sangat sederhana dan tradisional. Pengembangan industri rumah tangga terus dilakukan, karena industri ini mendayagunakan masyarakat sekitar dan biasanya memanfaatkan sumber daya alam lokal (Kuncoro dan Widjajanto, 2001).

\section{Biogas}

Biogas adalah gas yang terbentuk dari penguraian bahan organik dalam keadaan anaerobik (Wahyuni, 2011). Komposisi biogas terdiri dari: $50-80 \%$ metana, $\mathrm{CO}_{2}$, $\mathrm{H}_{2} \mathrm{~S}$ dan sedikit air, yang dapat dijadikan sebagai pengganti minyak tanah atau liquefied petroleum gas (LPG) (BPPT, 1997). Pada proses pembuatan biogas, dibutuhkan rangkaian alat berupa alat pencerna (digester), lubang masuk bahan baku, lubang pengeluaran lumpur (slurry) hasil pencernaan, dan pipa untuk mengalirkan biogas yang dihasilkan langsung ke kompor maupun untuk penerangan. Pada digester, terdapat bakteri metana yang mencerna bahan organik secara anaerob untuk menghasilkan biogas, yang selanjutnya dialirkan melalui pipa. Proses anerob untuk menghasilkan biogas ini dapat dijelaskan dalam 4 tahapan, yakni: hidrolisis, pembentukan asam, pembentukan asetat dan pembentukan metana (Subekti, 2011). Adapun keuntungan menggunakan biogas dibandingkan bahan bakar lainnya adalah:

1. Membantu memperlambat pemanasan global dengan menurunkan emisi gas rumah kaca seperti $\mathrm{CO}_{2}$.

2. Memanfaatkan dan mengurangi limbah seperti kotoran hewan maupun limbah hasil industri pangan.

3. Mewujudkan adanya bahan bakar yang ramah lingkungan.

4. Menghemat biaya yang dikeluarkan untuk membeli bahan bakar bagi para peternak ataupun pemilik industri yang menghasilkan limbah yang dapat dimanfaatkan menjadi biogas.

Sumber penghasil biogas yang paling umum berasal dari kotoran hewan seperti sapi yang mengandung banyak bakteri penghasil gas metana dalam perutnya (Franthena, 2015). Selain dari kotoran sapi, sumber potensial lainnya adalah limbah cair tahu yang mengandung banyak bahan 
organik. Apabila bahan organik tersebut diuraikan dengan benar, dapat menghasilkan gas metana dan karbon dioksida sebagai bahan dasar pembuatan biogas. Menurut penelitian Ridhuan (2012), hasil konversi bahan organik menjadi gas metana dalam limbah cair tahu mencapai $50 \%$ sehingga limbah cair tahu merupakan sumber yang potensial untuk dimanfaatkan menjadi biogas. Terdapat berbagai penelitian yang telah mencoba memanfaatkan limbah cair tahu menjadi biogas (Subekti, 2011; Ridhuan, 2012; Shaffitri et al., 2015). Dengan adanya penelitian-penelitian tersebut, limbah cair tahu terbukti memiliki potensi untuk diolah menjadi biogas, guna mengurangi pencemaran lingkungan dan menjaga sanitasi air.

\section{Sustainable Development Goals}

Sustainable Development Goals adalah serangkaian himbauan yang menyuarakan berbagai aksi seperti pemberantasan kemiskinan, menjaga lingkungan planet bumi, dan memastikan semua manusia menikmati hidup yang sejahtera dan damai (UNDP, 2012). Himbauan yang terdiri atas 17 poin ini pertama kali dirumuskan pada Konferensi PBB di Rio de Jainero pada tahun 2012. Dengan tujuan ingin menyelesaikan masalah mendesak seputar lingkungan, politik, dan ekonomi, maka dirumuskanlah ketujuh belas poin tersebut seperti:

1. No poverty (Tidak ada kemiskinan)

2. Zero hunger (Tidak ada kelaparan)

3. Good health and well being (Kesehatan yang baik)

4. Quality education (Pendidikan yang berkualitas),

5. Gender equality (Kesetaraan gender),

6. Clean water and sanitation (Air bersih dan Sanitasi),

7. Affordable and clean energy (Energi yang terjangkau dan bersih),
8. Decent work and economy growth (Pekerjaan yang pantas dan pertumbuhan ekonomi),

9. Industry, innovation and infrastructure (Industri, Inovasi dan Infrastruktur),

10. Reduced inequalities (Pengurangan ketidaksetaraan),

11. Sustainable cities and communities (Kota-kota dan komunitas yang berkelanjutan),

12. Responsible consumption and production (Konsumsi dan produksi yang bertanggung jawab),

13. Climate action (Iklim),

14. Life below water (Kehidupan di bawah air),

15. Life on land (Kehidupan di darat),

16. Peace, ustice and strong Institution (Perdamaian, keadilan dan institusi yang kuat), dan

17. Partnership for the goals (Kerja sama untuk mencapai SDGs).

Apabila semua poin dalam SDGs dapat dilakukan dengan baik, maka diharapkan terjadi peningkatan kualitas hidup secara berkelanjutan, khususnya bagi generasi masa depan. Indonesia merupakan salah satu negara yang tergabung dalam PBB juga berkomitmen untuk melakukan 17 poin ini. Sejak tahun 1970-2010, Indonesia merupakan salah satu dari 10 negara terbaik dalam peningkatan indeks pengembangan manusia (Human Development Index). Salah satu sektor di Indonesia yang mengalami perbaikan adalah menurunnya tingkat kemiskinan dari $19 \%$ menjadi $11 \%$ dalam rentang waktu tahun 2000-2015 (UNDP, 2015). Terlepas dari pencapaian Indonesia, negara ini juga masih menghadapi berbagai persoalan seperti kerusakan lingkungan dan perubahan iklim. Permasalahan ini sangat berdampak bagi pertumbuhan ekonomi di Indonesia karena sebagian besar sektor ekonomi di Indonesia mengandalkan sumber daya alam. Sayangnya, hal ini berbanding lurus 
dengan kekayaan alam yang dimiliki, Indonesia merupakan salah satu penghasil gas rumah kaca tertinggi di dunia serta memiliki laju deforestasi yang tinggi.

Faktor energi juga berpengaruh pada keberlanjutan dunia. Sebagian besar, energi didapatkan dari bahan bakar fosil, yang digunakan untuk keperluan utilitas listrik. Ditambah lagi, selain merupakan sumber daya yang tidak dapat diperbaharui, bahan bakar fosil juga sangat tidak ramah lingkungan. Energi merupakan kontributor dominan dalam terjadinya perubahan iklim, yaitu dengan menyumbang sekitar $60 \%$ dari gas rumah kaca secara global (UNDP, 2015).

\section{Produksi Gas Metana $\left(\mathrm{CH}_{4}\right)$}

Produksi biogas merupakan salah satu alternatif yang dapat dilakukan untuk mengolah limbah dengan kadar bahan organik yang tinggi, dan merupakan salah satu pendekatan terhadap pencapaian poin nomor 7 dalam SDGs yakni energi yang terjangkau dan bersih. Sebenarnya, implementasi produksi biogas skala rumahan telah dilakukan di Indonesia, seperti yang diinisiasi oleh BIRU (Biogas Rumah) yang telah membangun hingga 20 ribu unit di seluruh Indonesia. Akan tetapi, reaktor yang dihasilkan lebih berfokus pada pembuatan biogas dari kotoran ternak, bukan LCT sehingga dibutuhkan aplikasi reaktor biogas yang dibuat dari LCT.

Gas yang biasanya diproduksi dari LCT adalah gas metana $\left(\mathrm{CH}_{4}\right)$ mengingat air limbah tahu memiliki kandungan metana hingga lebih dari 50\% maupun hidrogen (Zhu et al., 2002; Subekti, 2011). Kegiatan produksi biogas dari LCT memberikan beberapa keuntungan, terutama bagi produsen tahu yang sebagian besar merupakan industri skala kecil. Adapun beberapa keuntungan tersebut mencakup: biogas dapat dijadikan sebagai energi terbarukan sehingga mengurangi penggunaan bahan bakar fosil, minimalisasi, efek rumah kaca dan pencemaran lingkungan sehingga memberikan dampak yang baik terhadap lingkungan, serta meningkatkan nilai ekonomi dari limbah tersebut (Subekti, 2011).

Gas metana $\left(\mathrm{CH}_{4}\right)$ merupakan gas yang tidak berbau dan berwarna, namun beracun dan mudah terbakar sehingga dapat membahayakan keselamatan manusia (Kaswinarni, 2007). Fermentasi metana biasanya terdiri atas dua tahapan yakni pembentukan asam dengan mikroorganisme acidogen, lalu dilanjutkan pembentukan metana oleh mikroorganisme metanogen (Zhu et al., 2002). Produksi $\mathrm{CH} 4$ yang dibuat dari LCT memanfaatkan bakteri methanogen, yakni bakteri yang menghasilkan metana dalam jumlah banyak sebagai produk samping metabolisme energi, yakni hingga 60\% (Ridhuan, 2012; Whitman et al., 2014). Ciri lain dari bakteri metanogen adalah merupakan bakteri anaerob, serta tergolong dalam Archaebacteria. Adapun substrat utama dalam pembuatan $\mathrm{CH}_{4}$ adalah $\mathrm{H}_{2}$ dan $\mathrm{CO}_{2}$, format, dan asetat.

Dalam memanfaatkan mikroorganisme anaerobik dari limbah, cair, terdapat beberapa jenis reaktor dan metode yang dapat digunakan seperti up flow an-up flow anaerobic filter process (UAFP), up flow anaerobic sludge blanket (UASB), anaerobic attached-film expanded-bed reactor (AAFEB), anaerobic fluidized bed reactor (AFBR), anaerobic mixed microflora under thermophilic conditions, dan thermophilic stirred anaerobic (TSA) reactor. Faisal et al. (2016) melakukan penelitian menggunakan reaktor TSA yang digunakan untuk menghasilkan $\mathrm{CH}_{4}$ dengan bantuan bakteri termofilik. Reaktor tersebut menggunakan sistem batch, memiliki pengaduk yang berputar $3 \mathrm{rpm}$, 
serta memiliki jangka suhu $45-55^{\circ} \mathrm{C}$. Dari hasil pengamatan, didapatkan bahwa penggunaan reaktor yang terbuat dari alumunium ini berpotensi untuk digunakan untuk menghasilkan $\mathrm{CH}_{4}$ yang dapat diubah menjadi listrik secara langsung. Hal ini karena biogas yang dihasilkan mengandung $\mathrm{CH}_{4}$ yang cukup tinggi, yakni $79,5 \%$ (Faisal et al., 2016). Selain dengan reaktor TSA, terdapat pula anaerobik baffled reactor yang dapat digunakan dalam mengolah LCT. Limbah cair dialirkan secara teratur sehingga mengalami kontak dengan lumpur aktif yang terdapat pada dinding-dinding sekat di reaktor (Kaswinarni, 2007). Dapat pula dilakukan penggabungan dua metode atau lebih untuk memahami lebih dalam terkait pemanfaatan LCT ini. Penelitian yang dilakukan oleh Setiawan dan Rusdjijati (2014) menggabungkan metode peningkatan kualitas produk Taguchi dengan penggunaan reaktor UASB untuk mengetahui faktor-faktor yang dominan dalam mempengaruhi pembentukan limbah cair tahu sebagai bahan bakar biogas. Dari hasil pengamatan yang dianalisis secara statistik, didapatkan bahwa faktor yang paling mempengaruhi kualitas gas secara berurutan adalah suhu digester, tingkat keasaman limbah cair, rasio karbon-nitrogen, serta berat kering limbah. Berdasarkan hasil penelitian, didapatkan bahwa kondisi optimum produksi $\mathrm{CH}_{4}$ dapat dicapai apabila suhu digester adalah $35^{\circ} \mathrm{C}, \mathrm{pH}$ limbah berada pada kisara 6,8 , serta dilakukan pengaturan rasio karbon-nitrogen dengan level tertinggi (Setiawan dan Rusdjijati, 2014).

Riduan (2012) melakukan penelitian terkait reaktor biogas yang berpotensi untuk diaplikasikan pada produsen tahu berskala kecil dan menengah mengingat alat yang digunakan cukup sederhana. Alat penghasil biogas yang diteliti terdiri atas dua bagian yakni reaktor atau pencerna berkapasitas 90 liter dan wadah pengumpul biogas yang keduanya terbuat dari plastik.
Adapun bahan yang diperlukan adalah 75 liter limbah cair tahu yang akan dimasukkan ke dalam reaktor. Reaktor yang dihasilkan harus ditutup agar didapatkan lingkungan anaerob, sehingga bakteri metanogen dapat melakukan fermentasi. Dari hasil penelitian, didapatkan bahwa biogas baru mulai dapat dihasilkan di dalam reaktor pada hari ke-5. Proses fermentasi dapat dilanjutkan dan biogas yang dihasilkan dapat dikumpulkan. Berdasarkan hasil pengamatan, diketahui bahwa jumlah biogas yang dihasilkan berbanding lurus dengan lama fermentasi sehingga semakin lama fermentasi dilakukan, maka semakin banyak pula zat biogas yang dapat diproduksi.

\section{Produksi Gas Hidrogen $\left(\mathrm{H}_{2}\right)$}

Penggunaan $\mathrm{H}_{2}$ sebagai sumber energi memiliki beberapa keuntungan jika dibandingkan dengan gas metana seperti nilai termal yang lebih tinggi, memiliki stabilitas $\mathrm{pH}$ dengan jangka yang lebih besar, serta sumber karbon yang dibutuhkan oleh mikroorganisme penghasil hidrogen bersifat lebih bervariasi. Produksi hidrogen dengan memanfaatkan LCT dapat dilakukan oleh jenis bakteri yang lebih banyak misalnya bakteri anoksigen fototrof seperti Rhodobacter sphaeroides dan $R$. capsulatus maupun bakteri anaerobik heterotrof seperti $C$. butyricum dan Methanobacterium sp. (Zhu et al., 2002). Namun, pembuatan $\mathrm{H}_{2}$ dengan bakteri anoksigen fototrof lebih diutamakan karena memiliki tingkat konversi substrat yang lebih tinggi dan dapat diaplikasikan pada limbah dengan kadar zat organik yang sangat tinggi (Zhu et al., 2002; Zheng et al., 2010).

Meskipun terdapat beberapa keuntungan dari pembuatan $\mathrm{H}_{2}$ berbahan dasar LCT, akan tetapi kandungan $\mathrm{NH}_{4}{ }^{+}$ dapat menjadi hambatan bagi bakteri anoksigen fototrof dalam memproduksi $\mathrm{H}_{2}$. 
Hal ini dipengaruhi oleh $\mathrm{NH}_{4}^{+}$yang menjadi inhibitor nitrogenase, yang mengkatalis proses reduksi $\mathrm{H}^{+}$menjadi $\mathrm{H}_{2}$ pada kondisi anaerobik tanpa adanya gas nitrogen (Koku, 2002). Untuk menghindari adanya efek buruk dari $\mathrm{NH}_{4}^{+}$, berbagai metode terbaru telah dibuat dan diaplikasikan. Salah satunya adalah dengan memfokuskan pada bakteri yang digunakan. Zheng (2010) melakukan preparasi Rhodobacter sphaeroides mutan yang bersifat glutamin auksotrof. Bakteri mutan ini diisolasi dari wild-type $\mathrm{R}$. spharoides lalu ditumbuhkan pada media serum pada kondisi anaerobik, selanjutnya diberikan mutagen berupa etil metana sulfonat (EMS). Dari hasil pengamatan, didapatkan bahwa mutan yang dihasilkan secara signifikan dapat menghasilkan hidrogen hingga dua kali lipat lebih banyak dibandingkan dengan $R$. spharoides yang ditemukan di alam.

Meskipun beberapa teknologi terkait produksi gas hidrogen telah dilakukan oleh berbagai peneliti, akan tetapi aplikasinya dalam skala industri rumah tangga masih sangat terbatas. Terlebih, penelitian yang telah dilakukan masih berskala laboratorium, sehingga diperlukan penelitian lebih lanjut terkait penerapan produksi biogas pada skala yang lebih besar.

\section{Potensi Bahan Baku Limbah Cair Tahu di Banten untuk Pembuatan Biogas}

Banten merupakan salah satu provinsi yang memproduksi biji kedelai. Produksi kedelai di Provinsi Banten terus meningkat, dimana pada tahun 2014 adalah sebesar 6,38 ribu ton biji kering menjadi 7,06 ribu ton biji kering pada tahun 2015 (BPS, 2016). Biji kedelai ini dapat diolah menjadi berbagai produk, salah satunya adalah untuk memproduksi tahu. Menurut data dari Kemenperin RI, terdapat sebanyak 7 pabrik tahu skala besar di provinsi Banten, yaitu PT. Family Baru,
PT. Gintung Sari Jaya, Industri Tahu Mekarsari, PT. Mitra Boga Segar, PT. Tahu Dua Sekawan, PT. Tahu Sari Wangi, dan PT. Usaha Jaya (Kemenperin, 2016). Selain ketujuh pabrik tahu skala besar tersebut, kebanyakan pabrik tahu berskala kecil dan menengah (skala rumah tangga) tidak terdaftar pada data statistik milik Kemenperin.

Perusahan tahu baik perusahaan skala besar maupun skala kecil tidak hanya menghasilkan produk tahu, namun juga menghasilkan hasil sampingan berupa limbah padat dan limbah cair tahu. Limbah cair tahu dapat berasal dari proses pencucian kedelai, perendaman kedelai, penirisan, dan pemisahan padatan dengan cairan tahu. Oleh karena itu, jumlah limbah cair tahu cukup banyak, dimana jumlahnya dapat mencapai 94,5\% dari total bahan baku (kacang kedelai dan air) yang digunakan (Said et al., 2015). Limbah cair tahu sangat berpotensi dijadikan biogas karena konversi bahan organiknya mampu menghasilkan sebanyak $50 \%$ gas metana (Ridhuan, 2012).

\section{Analisis Ekonomi Pembuatan Biogas Berbahan Dasar Limbah Cair Tahu di Provinsi Banten}

Pada bagian awal telah dijelaskan bahwa alat yang dibutuhkan dalam pembuatan biogas berupa tangki sebagai tempat menyimpan limbah sementara atau disebut juga dengan storage tank, alat pencerna (digester) dan pipa. Dengan kata lain, pembuatan biogas tidak membutuhkan peralatan yang rumit, sehingga masih dapat dilakukan oleh industri berskala rumah tangga. Priyadi dan Subiyanta (2016) menunjukkan bahwa biaya investasi yang dibutuhkan untuk instalasi biogas, pembelian tanah $\left(20 \mathrm{~m}^{2}\right)$, dan generator adalah Rp. 25.000.000 dengan biaya operasi sebesar Rp. 8.900.000/tahun. Biogas yang dihasilkan dapat langsung dimanfaatkan untuk 
menyalakan lampu petromaks, kompor gas, atau diubah menjadi energi listrik melalui generator. Dengan daya generator sebesar 1.200 watt, dapat dihasilkan energi listrik sebanyak 28.800 watt/hari (Priyadi dan Subiyanta, 2016).

Salah satu jenis reaktor yang juga telah diterapkan oleh produsen tahu di Boyolali adalah fixed dome anaerobic reactor yang memanfaatkan proses anaerobik mikroorganisme (Faisal et al., 2016). Limbah cair tahu yang dihasilkan dari pabrik dengan kapasitas 600 kg setiap harinya disimpan selama sekitar tiga jam di dalam tangki penyimpanan dengan volume yang berukuran $0,77 \mathrm{~m}^{3}$, lalu dialirkan ke reaktor dengan volume $30 \mathrm{~m}^{3}$ dan didiamkan selama 6 hari sebelum akhirnya limbah sisa yang tidak menghasilkan biogas akan dibuang ke sungai. Hasil penelitian oleh Kaswinarni (2007) menunjukkan bahwa biaya operasional sekitar Rp. 60.000/bulan, biaya operasional $/ \mathrm{m}^{3}$ limbah/bulan Rp. 12.000 dan beban biaya bangunan IPAL $/ \mathrm{m}^{3}$ air limbah sekitar Rp. 5.000.000 dengan biaya investasi totalnya adalah sekitar $\mathrm{Rp}$. 31.000.000. Sistem penanganan limbah ini perlu dilakukan maintenance secara berkala agar hasil pengolahan limbah tetap maksimal dan efisien. Dana yang dikeluarkan oleh masyarakat yang menggunakan biogas ini tergolong cukup murah. Di Banyumas, masyarakat hanya perlu mengeluarkan dana sebesar Rp. 15.000/bulan/keluarga sebagai harga untuk perawatan alat-alat tersebut (Andrianto, 2015). Dengan melihat dari beberapa contoh di atas, dapat disimpulkan bahwa memungkinkan bagi produsen tahu di Provinsi Banten untuk melakukan pengolahan limbah cair tahu menjadi biogas, dengan syarat kapasitas minimum pabrik adalah sekitar $600 \mathrm{~kg}$.

\section{Manfaat Produksi Biogas Dilihat dari Berbagai Aspek}

Pembuatan biogas dari limbah cair tahu ini dapat memberikan manfaat dari berbagai aspek, seperti aspek lingkungan, aspek ekonomi, aspek sosial, dan aspek kesehatan. Pembuatan biogas dari limbah cair tahu ini dapat digunakan sebagai pengolahan limbah alami yang dapat menyelesaikan masalah limbah cair tahu yang jumlahnya cukup banyak. Hal ini dapat membuat jumlah limbah cair tahu yang dibuang menjadi berkurang dan lingkungan menjadi lebih bersih dan nyaman. Pembuatan biogas ini juga dapat mengurangi permasalahan lingkungan, seperti mengurangi polusi udara, polusi tanah, dan pemanasan global. Selain itu, biogas memiliki banyak manfaat dan dapat digunakan sebagai pengganti energi. Energi alternatif berupa biogas ini memiliki harga yang lebih murah dibandingkan dengan energi lainnya seperti BBM dan LPG. Biogas ini memiliki harga yang lebih murah karena mampu menghasilkan energi yang dapat diperbaharui dan mudah diperbanyak, serta biaya modal, proses, dan pemeliharaannya yang ekonomis atau tidak terlalu mahal. Biogas dari limbah cair tahu ini dapat menghemat pengeluaran masyarakat karena memiliki harga yang lebih murah dan tentunya dengan kualitas yang tinggi, serta aman karena tidak mudah meledak. Di sisi lain, biogas yang diproduksi akan menghasilkan energi dan hasil samping berupa pupuk yang dapat meningkatkan nilai ekonomis dari limbah cair tahu, yang pada akhirnya dapat dijual untuk meningkatkan pendapatan produsen tahu tersebut. Hal ini menyebabkan para produsen tahu dapat hidup dengan lebih sejahtera. Selain itu, pembuatan biogas ini juga dapat memberikan manfaat dalam aspek kesehatan karena dapat mengurangi bau yang akan memberikan dampak negatif bagi kesehatan manusia (Wahyuni, 2011). 


\section{KESIMPULAN}

Limbah cair dari pabrik tahu merupakan suatu bahan yang sangat berguna untuk pembuatan produk-produk berbasis energi dan agrikultur. Penggunaan limbah cair dari pabrik tahu ini dapat menurunkan efek kerusakan lingkungan yang ditimbulkan apabila limbah cair ini dibuang begitu saja. Limbah cair dari pabrik tahu dapat digunakan sebagai bahan dasar dalam pembuatan biogas, yaitu sebagai penghasil gas metana serta gas hidrogen yang memiliki nilai termal yang tinggi. Produksi biogas dapat memberikan berbagai dampak positif apabila ditinjau dari berbagai aspek seperti aspek ekonomi, sosial, lingkungan, dan kesehatan. Dari hasil pemaparan, pembuatan biogas memungkinkan untuk diaplikasikan oleh produsen tahu yang berada di Indonesia, termasuk yang berlokasi di Provinsi Banten. Selain untuk meningkatkan nilai ekonomi dari limbah cair tahu, hal ini juga dapat menjadi salah satu upaya dalam pencapaian Sustainable Development Goals, terutama pada poin energi terjangkau dan bersih.Daging kupang merah setelah dilakukan perendaman pada jus semanggi 10\%, 20\%, 30\% dan lama waktu perendaman 60 menit, 90 menit dan 120 menit diperoleh perlakuan terbaik pada konsentrasi jus semanggi 30\% waktu perendaman 120 menit yang dapat menurunkan cemaran logam berat pada kupang merah yaitu $\mathrm{Cu}$ dari 47,49 ppm menjadi 19,86 ppm (turun 58,18\%), $\mathrm{Pb}$ dari 21,30 ppm menjadi 0,886 ppm (turun 95,84\%), Cr dari 2,33 ppm menjadi 0,758 ppm (turun 67,509 \%), Cd dari 1,64 ppm menjadi $0,81 \mathrm{ppm}$ (turun 50,67\%), Hg dari $0,54 \mathrm{ppm}$ menjadi $0,02 \mathrm{ppm}$ (turun 95,55\%). Karakteristik daging kupang merah setelah dilakukan perendaman dalam jus semanggi yaitu kadar protein $9,10 \%$, kadar abu $1,78 \%$ dan kadar air dari $84,51 \%$

\section{DAFTAR PUSTAKA}

Andrianto, A. (2015) Biogas from Tofu Industry Waste Sustains Energy Needs. Tersedia pada: https://nasional.tempo.co/read/6341 58/biogas-from-tofu-industry-wastesustains-energy-needs (Diakses: 29 November 2018).

Arifin, F. (2012) Uji kemampuan chlorella sp. sebagai bioremidiator limbah cair tahu. UIN Maulana Malik Ibrahim.

[BPPT] Badan Pengkajian dan Penerapan Teknologi (1997) Teknologi Pengolahan Limbah Tahu-Tempe dengan Proses Biofilter Anaerob dan Aerob. Tersedia pada: http://www.enviro.bppt.go.id (Diakses: 14 Oktober 2018).

[BPS] Badan Pusat Statistik (2014) Perusahaan Industri Pengolahan. Tersedia pada: https://www.bps.go.id/subjek/view/i d/9\#subjekViewTab1 (Diakses: 20 November 2018).

[BPS] Badan Pusat Statistik (2016) Produksi Padi, Jagung, dan Kedelai 2015, Berita Resmi Statistik. Jakarta. Tersedia pada: https://banten.bps.go.id/backend/brs _ind/brsInd-20151102144009.pdf.

Faisal, M. et al. (2016) "Treatment and Utilization of industrial Tofu Waste in Indonesia," Asian Journal of Chemistry, 28(3), hal. 501-507.

Franthena, A. (2015) Pemanfaatan Limbah Sekam Padi dan Kotoran Sapi dalam Pembuatan Biogas Menggunakan Alat Anaerobic Biodiegester. Universitas Diponegoro.

Husin, A. (2003) Pengolahan Limbah Cair Industri Tahu Menggunakan Biji Kelor (Moringa oleifera Seeds) Sebagai Koagulan. Medan.

Kaswinarni (2007) Kajian Teknis Pengolahan Limbah Padat dan Cair Industri Tahu. Universitas Diponegoro. 
[Kemenperin] Kementerian Perindustrian (2016) Perkembangan Jumlah Unit Usaha Industri Besar dan Sedang Indonesia. Tersedia pada: http://kemenperin.go.id/statistik/ibs_ indikator.php?indikator=1 (Diakses: 14 Oktober 2018).

Koku, H. (2002) "Aspects of the metabolism of hydrogen production by Rhodobacter sphaeroides," 27, hal. 1315-1329.

Kuncoro, M. dan Widjajanto, K. (2001) "Analisis Profil dan Masalah Industri Kecil dan Rumah Tangga: Studi Kasus di Kabupaten Ngawi, Jawa Timur," Jurnal Ekonomi Pembangunan, 6(1), hal. 33-51.

Kusumawati, K., Muhartini, S. dan Rogomulyo, R. (2015) "Pengaruh konsentrasi dan frekuensi pemberian limbah tahu terhadap pertumbuhan dan hasil bayam (Amaranthus tricolor L.) pada media pasir pantai," Vegetalika, 4(2), hal. 48-62.

Nohong, N. (2010) "Pemanfaatan Limbah Tahu sebagai Bahan Penyerap Logam Krom , Kadmiun dan Besi Dalam Air Lindi TPA," Jurnal Pembelajaran Sains, 6(2), hal. 257269.

Priyadi, F. dan Subiyanta, E. (2016) "Studi Potensi Biogas dari Kotoran Ternak Sapi sebagai Energi Alternatif untuk Penerangan," in Prosiding Elektronik SNIRT. Cirebon: Universitas Tujuh Belas Agustus 1945 Cirebon.

Rianti, A. et al. (2018) "Potensi Ekstrak Kulit Petai (Parkia speciosa) sebagai Sumber Antioksidan," Jurnal Dunia Gizi, 1(1), hal. 10-19.

Ridhuan, K. (2012) "Pengolahan Limbah Cair Tahu Sebagai Energi Alternatif Biogas yang ramah lingkungan," TURBO, 1(1), hal. 1-9.

Sadzali, I. (2010) "Potensi limbah tahu sebagai biogas," Jurnal UI untuk Bangsa Seri Kesehatan, Sains, dan Teknologi, 1(2), hal. 62-69.
Said, N. I. et al. (2015) Teknologi Pengolahan Limbah Tahu-Tempe dengan Proses Biofilter Anaerob dan Aerob. Tersedia pada: http://www.kelair.bppt.go.id/Sitpa/A rtikel/Limbahtt/limbahtt.html (Diakses: 29 November 2018).

Setiawan, A. dan Rusdjijati, R. (2014) "Peningkatan Kualitas Biogas Limbah Cair Tahu dengan Metode Taguchi," in Prosiding SNATIF Ke1. Kudus: Universitas Muria Kudus, hal. 35-40.

Shaffitri, L. R., Syaukat, Y. dan Ekayani, M. (2015) "Peranan BUMDes dalam Pengelolaan Limbah Cair Tahu dan Pemanfaatan Biogas," Risalah KEbijakan Pertanian dan Lingkungan, 2(2), hal. 137-143.

Siswoyo, E. dan Hermana, J. (2017) "Pengaruh Air Limbah Industri Tahu terhadap Laju Pertumbuhan Tanaman Bayam Cabut (Amaranthus tricolor)," Jurna Sains dan Teknololgi Lingkungan, 9(2), hal. 105-113.

Subekti, S. (2011) "Pengolahan limbah cair tahu menjadi biogas sebagai bahan bakar alternatif," in rosiding Seminar Nasional Sains dan Teknologi ke-2. Semarang: Universitas Wahid Hasyim, hal. 61-66.

Tangerang Pos (2017) Pabrik Tahu Asal Tangsel, Diduga Cemari Sungai Cisadane. Tersedia pada: ttps://tangerangpos.com/2017/03/23/ pabrik-tahu-asal-tangsel-didugacemari-sungai-cisadane/ (Diakses: 19 November 2018).

[UNDP] United Nations Development Programme (2012) What are the Sustainable Development Goals? Tersedia pada: http://www.undp.org/content/undp/e n/home/sustainable-developmentgoals.html. (Diakses: 20 November 2018). 
[UNDP] United Nations Development Programme (2015) About Indonesia. Tersedia pada: http://www.id.undp.org/content/indo nesia/en/home/countryinfo/. (Diakses: 20 November 2018).

Wahyuni, S. (2011) Menghasilkan Biogas dari Aneka Limbah. Jakarta: Agromedia Pustaka.

Wahyuningsih, S. (2016) "Konsumsi dan Neraca Penyediaan - Penggunaan Kedelai," Buletin Konsumsi Pangan, 7(1), hal. 31-42.

Whitman, W., Bowen, T. dan Boone, D. (2014) "The methanogenic bacteria," in Rosenberg, E. et al. (ed.) In The Prokaryotes. Berlin: Springer, hal. 123-163.

Widyastuti, E., Sukanto, S. dan Setyaningrum, N. (2015) "Pengaruh Limbah Organik terhadap Status Tropik , Rasio N/P serta Kelimpahan
Fitoplankton di Waduk Panglima Besar Soedirman Kabupaten Banjarnegara," Biosfera, 32(1), hal. 35-41.

Zheng, G. H., Wang, L. dan Kang, Z. H. (2010) "Feasibility of biohydrogen production from tofu wastewater with glutamine auxotrophic mutant of Rhodobacter sphaeroides," Renewable Energy. Elsevier Ltd, 35(12), hal. 2910-2913. doi: 10.1016/j.renene.2010.04.030.

Zhu, H. et al. (2002) "Hydrogen production as a novel process of wastewater treatment - studies on tofu wastewater with entrapped R. sphaeroides and mutagenesis," International Journal of Hydrogen Energy, 27(11-12), hal. 1349-1357. 